\title{
Effect of Processing Method on Carotenoid Profiles of Oils from Three Varieties of Nigerian Palm Oil (Elaise guinensis)
}

\author{
Sunday Onyekwere Eze', Joshua Nkechukwu Orji', Victor Uchenna Okechukwu2 ${ }^{2}$, \\ Daniel Omeodisemi Omokpariola ${ }^{2}$, Theresa Chisom Umeh ${ }^{2 *}$, Nwanneamaka Rita Oze ${ }^{3}$ \\ ${ }^{1}$ Department of Pure and Industrial Chemistry, Abia State University Uturu, Nigeria \\ ${ }^{2}$ Department of Pure and Industrial Chemistry, Nnamdi Azikiwe University, Awka, Nigeria \\ ${ }^{3}$ Department of Chemistry, Federal University of Technology, Owerri, Nigeria \\ Email: *umehchi871@gmail.com
}

How to cite this paper: Eze, S.O., Orji, J.N., Okechukwu, V.U., Omokpariola, D.O., Umeh, T.C. and Oze, N.R. (2021) Effect of Processing Method on Carotenoid Profiles of Oils from Three Varieties of Nigerian Palm Oil (Elaise guinensis). Journal of Biophysical Chemistry, 12, 23-31. https://doi.org/10.4236/jbpc.2021.123003

Received: July 5, 2021

Accepted: August 27, 2021

Published: August 30, 2021

Copyright $\odot 2021$ by author(s) and Scientific Research Publishing Inc. This work is licensed under the Creative Commons Attribution International License (CC BY 4.0).

http://creativecommons.org/licenses/by/4.0/

\section{(c) (i) Open Access}

\begin{abstract}
This study assessed the effect of processing method on the carotenoid profile of oil from three varieties of Nigerian oil palm fruits (Elaise guinensis). Specific varieties of the Elaise guinensis, which are the dura, pesifera and tenera were obtained from National Institute for Oil Palm Research (NIFOR) in Edo state, Nigeria. The samples were divided into two and processed using two different methods as commonly practiced in south-eastern Nigeria, the hot and cold processes. The oil extracted from each of the processes was then analyzed for oil characteristics using standard analytical methods while the carotenoid profile was analyzed using HPLC C-21 column. The results generated were subjected to the one-way analysis of variance (ANOVA). The results of carotenoid constituent identified include: lutein, neurosporene (trans), neurosporene (cis), $\alpha$-Zeacarotene(cis), $\alpha$-Zeacarotene(trans), phytoene, phytofluene, $\beta$-zeacarotene, 13 and 13' cis $\alpha$-carotene, 13 cis $\beta$-carotene, trans $\alpha$-carotene, 9 cis $\alpha$-carotene, trans $\beta$-carotene, $\alpha$ carotene a(cis), $\alpha$-carotene $\mathrm{b}$ (cis), $\alpha$-carotene (trans), $\gamma$-carotene (trans), $\gamma$-carotene $\mathrm{b}(\mathrm{cis})$, lycopene (cis) and lycopene (trans). The results of physicochemical characteristics of the oil samples extracted range from $0.922 \pm 0.004-0.916 \pm 0.001$ for specific gravity (SG), $8.10 \pm 0.17-4.88 \pm 0.04 \mathrm{mg} \mathrm{KOH} / \mathrm{g}$ for acid value, $4.29 \% \pm 0.02 \%-$ $2.44 \% \pm 0.02 \%$ for free fatty acid value (FFA), $6.00 \pm 0.21$ to $204.67 \pm 0.98$ $\mathrm{mgKOH} / \mathrm{g}$ for saponification value and $9.53 \pm 0.23-5.25 \pm 0.33 \mathrm{mEq} / \mathrm{kg}$; for peroxide value while the carotenoids values were between $53.735 \pm 0.10$ and $123.389 \pm 0.20 \mathrm{mg} / 100 \mathrm{~g}$. From the result, we can observe that the main constituent of the palm oil carotenoid is the $\beta$-carotene which makes up to about $80 \%$ of the total carotene. Statistical analysis revealed that no significant dif-
\end{abstract}


ference exists between the mean of each of the processing methods on the carotenoid profile of the oil sample analyzed.

\section{Keywords}

Elaise guinensis, Carotenoid, Acid Value, Free Fatty Acids, $\beta$-Carotene, Palm Oil, Nigeria

\section{Introduction}

The oil palm tree is one of the important economic crops in the tropics. It is a monocotyledon belonging to Genus of Elaeis. The genus Elaeis consists of two species, namely E. guinensis and E. oleifera. E. guinensis originates from West Africa and the commercial planting material is mainly of this species, yielding three types of fruit, namely dura (thick shell), pisifera (without shell), and tenera (thin shell). E. oleifera is a stumpy plant of South American origin and its oil is characterized by a high oleic acid content and linoleic acid content and lower content of palmitic and other saturated acids [1]. The oil palm fruit bears two types of oils, one derived from fleshy but fibrous layer, the mesocarp and usually known as the "palm oil" and the other derived from the nut seed, the palm kernel and usually known as the "palm kernel oil". The composition of palm oil is rather unique when compared to that of the other major fats and oils [2]. Palm oil is one of the most widely used edible oil in various food products, by households and by foodstuff factories. Its use is numerous in particular in manufacture of industrial products such as margarines, shortenings, cooking oils, confectionery fats and has been usefulness for other food applications. Crude palm oil contains approximately $1 \%$ of minor components: carotenoids, vitamin $\mathrm{E}$ (tocopherols and tocotrienols), sterols, phospholipids, glycolipids, terpenes and aliphatic hydrocarbons, and other trace impurities [3]. The most important are carotenoids and vitamin E, both of which possess important physiological properties.

Carotenoids are made-up of a pigment family containing over 700 different species, consisting of a C- 40 polyene backbone with conjugated double bonds. Their structure could be modified at one or both ends, that is, cyclization or the introduction of oxygen to yield different species. The carotenoids give the palm oil its characteristic colour [4] [5]. These pigments have been used mainly in food, pharmaceutical, and cosmetic industries. Carotenoids also play an important potential role by acting as biological antioxidants, protecting cells and tissues from the damaging effects of free radicals. Carotenoids are the precursors of vitamin $\mathrm{A}$, with $\alpha$ carotene having the highest provitamin A activity. Due to the beneficial properties of carotenoids and their high quantitative levels in palms fruits, their identification and quantification have been performed in the mesocarp of several species (buriti, pupunha and tucuma).

However, the oils extracted from palm fruits have only been characterized spectrophotometrically for their total carotenoid content [6]. There is little lite- 
rature on the effects of traditional processing method of palm oil on its carotenoid profile. Therefore, the present work aims to assess the effects of processing methods on physicochemical properties and carotenoids' profiles of oils from three varieties of Elaeis guinensis.

\section{Materials and Methods}

\subsection{Sample Collection and Preparation}

The palm fruits were collected from National Institute for Oil Palm Research (NIFOR) Edo State, Nigeria and duly identified by a taxonomist from the department of Botany, Abia State University Uturu, Abia State, Nigeria. The three varieties were separated into two portions each, where each variety was extracted one part by hot process and the other part by cold process using the palm oil extraction method as practiced locally in the south-eastern part of Nigeria. The oils were stored in an Amber bottle under room temperature till further analysis.

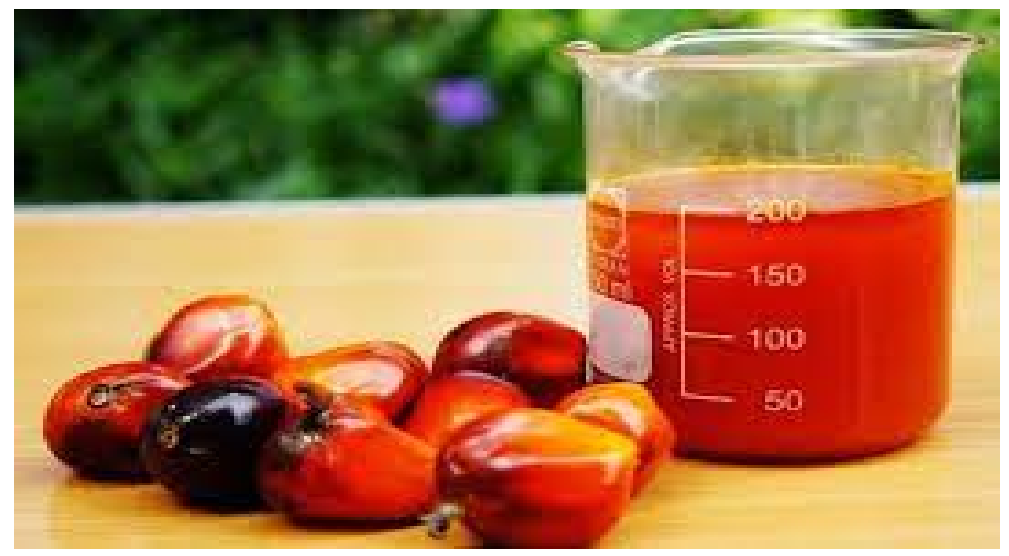

Samples used for analysis

\subsection{Physiochemical Characterization}

The percentage free fatty acid, iodine value accomplished by gravimetric and titrimetric methods, saponification value using reflux boiling and titration methods was performed as described by Pearson [7]. While viscosity, peroxide and acid values were determined by standard method as described by AOCS [8].

\subsection{Carotenoid Profiles}

$5 \mathrm{~g}$ of each oil sample and $5 \mathrm{ml}$ of $50 \%$ ethanolic $\mathrm{KOH}$ (Sigma-Aldrich) of 92\% purity were heated at $50^{\circ} \mathrm{C}$ in a water bath under a stream of nitrogen for 30 mins. The saponified sample was then cooled to room temperature and extracted with $50 \mathrm{ml}$ portion of petroleum ether until the supernatant becomes colourless. The pooled petroleum ether extract was washed four times with 50 $\mathrm{ml}$ portion of distilled water and dried over anhydrous sodium sulphate. Then the extract was dried in a rotary evaporator at $50^{\circ} \mathrm{C}$. Then the dried extract was dissolved in a known volume of mobile phase containing an antioxidant before it will be injected into the RP-HPLC-UV visible. The carotene profiles analysis was 
performed using a Reverse Phase HPLC (Agilent, USA) with Waters 990 series UV-Visible detector at spectral range of " 222 - $800 \mathrm{~nm}$ ”. With C18 column (4.6 $\mathrm{mm} \times 25 \mathrm{~cm}$; stainless steel $5 \mu \mathrm{m}$ spherical particles) and the solvent system was acetonitrile: dichloromethane $(89: 11 \mathrm{v} / \mathrm{v})$ at flow rate of $1.0 \mathrm{ml} \cdot \mathrm{min}^{-1}$ as described by [9].

\subsection{Statistical Analysis of Data}

All experiments were carried out in triplicate. Data were expressed as mean \pm SD (Standard deviation). The data were analyzed for significant differences among means using one-way analysis of variance (ANOVA). Duncan's multiple range test was used as a post hoc comparison of statistical significance ( $\mathrm{p}$ values < 0.05). All statistical analyses were performed using SPSS version 20, 2018.

\section{Results and Discussion}

Table 1 reveals the physicochemical parameters of oil extracted from the three varieties of Elaeis guinensis respectively. The results indicated that Iodine values ranged between from $47.87 \pm 0.23$ to $49.33 \pm 0.12$ wiji, Acid value from $8.10 \pm$ $0.17-4.88 \pm 0.04 \mathrm{mgKOH} / \mathrm{g}$, free fatty acid value from $2.35 \% \pm 0.01 \%$ to $3.97 \%$ $\pm 0.06 \%$, saponification value from $6.00 \pm 0.21$ to $204.67 \pm 0.98 \mathrm{mgKOH} / \mathrm{g}$, peroxide value range between $5.25 \pm 0.33$ to $9.53 \pm 0.23 \mathrm{mEq} / \mathrm{kg}$; while the carotenoids values were between $53.735 \pm 0.10$ and $123.389 \pm 0.20 \mathrm{mg} / 100 \mathrm{~g}$. Statistical analysis revealed that slight significant difference exists between the mean of one sample and another for each of the parameters determined.

Table 1. Physicochemical properties of the extracted palm oil.

\begin{tabular}{cccccc}
\hline Sampling codes & Iodine value (Wiji) & $\begin{array}{c}\text { Peroxide value } \\
(\mathrm{Meq} / \mathrm{kg})\end{array}$ & $\begin{array}{c}\text { Saponification value } \\
(\mathrm{mgKOH} / \mathrm{g})\end{array}$ & $\begin{array}{c}\text { Acid value } \\
(\mathrm{mgKOH} / \mathrm{g})\end{array}$ & $\begin{array}{c}\text { Free fatty acid value } \\
(\%)\end{array}$ \\
\hline MS1 & $48.53 \pm 0.31$ & $49.02 \pm 0.20 \mathrm{~b}$ & $197.33 \pm 0.58$ & $4.88 \pm 0.04$ & $2.44 \pm 0.02$ \\
MS2 & $48.55 \pm 0.30$ & $48.55 \pm 0.30 \mathrm{~b}$ & $196.99 \pm 0.51$ & $5.14 \pm 0.05$ & $2.49 \pm 0.03$ \\
MS3 & $49.02 \pm 0.20$ & $48.52 \pm 0.31 \mathrm{~b}$ & $197.04 \pm 1.15$ & $5.36 \pm 0.03$ & $2.35 \pm 0.01$ \\
MS4 & $48.52 \pm 0.31$ & $48.50 \pm 0.29 \mathrm{~b}$ & $198.02 \pm 1.03$ & $6.60 \pm 0.02$ & $3.01 \pm 0.01$ \\
MS5 & $48.50 \pm 0.29$ & $48.53 \pm 0.31 \mathrm{~b}$ & $199.32 \pm 0.40$ & $6.51 \pm 0.04$ & $2.89 \pm 0.02$ \\
TCP & $49.07 \pm 0.23$ & $8.27 \pm 0.12 \mathrm{a}$ & $203.33 \pm 0.58$ & $7.95 \pm 0.12$ & $3.97 \pm 0.06$ \\
THP & $49.07 \pm 0.29$ & $7.87 \pm 0.21 \mathrm{a}$ & $202.69 \pm 0.58$ & $7.53 \pm 0.23$ & $3.77 \pm 0.06$ \\
PCP & $48.77 \pm 0.29$ & $6.93 \pm 0.23 \mathrm{a}$ & $201.33 \pm 0.58$ & $6.93 \pm 0.23$ & $3.47 \pm 0.12$ \\
PHP & $47.87 \pm 0.23$ & $7.87 \pm 0.12 \mathrm{a}$ & $199.33 \pm 0.58$ & $5.67 \pm 0.12$ & $2.83 \pm 0.06$ \\
DCP & $49.33 \pm 0.12$ & $9.53 \pm 0.23 \mathrm{a}$ & $204.67 \pm 0.98$ & $8.57 \pm 0.06$ & $4.29 \pm 0.02$ \\
DHP & $49.07 \pm 0.2$ & $7.53 \pm 0.06 \mathrm{a}$ & $202.67 \pm 1.6$ & $8.10 \pm 0.17$ & $4.05 \pm 0.09$ \\
\hline
\end{tabular}

*Values are Means \pm standard deviations of triplicate determinations. Values in the same row having the same superscript letters are not significantly different ( $\mathrm{p}<0.05$ ). MS 1-Ahunta market, MS 2-Eke Okigwe market, MS 3-Orie Ugba market, MS 4-Ubani Market, MS 5-Ukwunwangwu market, DHP-Dura hot process, DCP-Dura cold process, PHP-pesifera hot process, PCP-Pesifera cold process, THP-Tenera hot process, TCP-Tenera cold process. 
Iodine value is an important property of oil, which measures the unsaturation of oil and is a useful criterion for purity. The iodine values observed across the samples were generally low. The relative low iodine value in oils may be indicative of the presence of few unsaturated bonds and hence low susceptibility to oxidative rancidity. The hot processed oils had higher iodine values which show greater liability of the oil to go rancid by oxidation which might be caused by the heat effect. The values were low compared to results of [10] on oil extracted from Akparata seed and prescribed 75 - $94 \mathrm{Wij} s$ value for vegetable oils [11], but within $53.1 \pm 0.4$ and $56 \pm 0.3 \mathrm{~g} \mathrm{I} 2 / 100 \mathrm{~g}$ values reported by [12] on crude palm oil. Generally, oils and fats with low iodine values enjoy the advantages of being less susceptible to oxidative spoilage than those with higher values. The oil samples obtained from the hot and cold process of specific varieties had higher saponification values as compared with market samples. The highest value was observed in cold process Dura with a value of $204.69 \pm 0.98$ followed by cold processed tenera with a value of $203.33 \pm 0.58$, significant difference $(P<0.05)$ were observed between the processed seed oil samples. The higher the saponification value, the higher the unsaturated level of the oil, it can thus be deduced that hot process palm oil possess more unsaturated fatty acids than those of cold process and market samples [13] [14].

Saponification value (SV) is used to determine the saponification number of a fat or oil which is an index of the average molecular weight of the triacylglyceride in the sample [9]. Saponification Value is an important parameter for characterizing the industrial use of oil, specifically for soap production. The high saponification value is suggestive of industrial potentials of the oil especially in soap making, but it was observed that there are slight but significant variations in the oils obtained through the different treatments. Due to an inverse relationship between saponification number and molecular weight of fatty acids in oil, it can be inferred that the oils contain a great number of fatty acids of low molecular weight and could be employed in soap making. Oils with low Saponification value can be used for the production of soap, candle, and raw materials for lubricants [15].

The peroxide value is used to monitor the development of rancidity through the evaluation of the quantity of peroxide. The hot and cold processed oil sample of the three varieties had low peroxide values compared to the market samples, the cold processed oil samples had $8.27 \pm 0.12,6.93 \pm 0.23$ and $7.53 \pm 0.06$ $\mathrm{mEq} / \mathrm{kg}$ in tenera, pisifera and dura respectively. While the hot process had peroxide values of $7.87 \pm 0.12,9.53 \pm 0.06$ and $7.93 \pm 0.12 \mathrm{mEq} / \mathrm{kg}$ in Tenera, pisifera and Dura respectively. This finding implied that the hot processed oil had higher peroxide value than the cold processed oil though the values were not really significant. The primary products of lipid oxidation are hydro peroxides; therefore, the result of peroxide value gives a clear indication of oxidation [16]. Oils with higher peroxide value have been reported to have greater chances of going rancid [17] [18]. Rancidity begins to be noticeable when the peroxide value is well above $10 \mathrm{mEq} / \mathrm{kg}$ [7]. 
Acid value is a factor that significantly affects the use of oil for industrial applications or human nutritional end uses [12]. The acid values of all the processed samples were generally below the stipulated permitted maximum values of $10 \mathrm{mg}$ $\mathrm{KOH} / \mathrm{g}$ [8]. There were no significant differences $(\mathrm{p}<0.05)$ observed. The quality of oil is determined by the acid value of the oil, the higher the acid value the lower the quality of the oil. The amount of free fatty acid in palm oil is an indicator of the quality of the palm oil, and high level of free fatty acid is a presage of lipid oxidation [19]. The value of free fatty acid ranges from $2.44 \%$ to $4.29 \%$. The result was within 3\% - 5\% maximum permissible values for Free Fatty Acid contents in a good quality palm oil [20]. Acid Value and Free Fatty Acid are analytically used to detect the level of unesterified fatty acid in a lipid sample to define its quality [13].

The characteristics of the carotenoids identified in the analyzed oil samples are revealed in Table 2. Carotenoids are a class of tetraterpenoids that play an important role in plants and animals [21]. Ten (10) different carotenoids were detected in all the oil samples, which includes: beta-cryptoxanthin, lycopene, alpha-carotene, beta-carotene, lutein, zea-xanthin, antheraxanthine, anstaxanthin, violaxanthin and neoxanthin. Of all the carotenoids detected, beta-craotenoid has the highest concentration in the all the oil samples with a value of $84.200 \pm$ $0.10 \mathrm{mg} / 100 \mathrm{~g}$ in Eke Okigwe sample, followed by a value of $84.182 \pm 0.10$ $\mathrm{mg} / 100 \mathrm{~g}$ in Ahunta and Orie Ugba market. The least value for beta-carotenoid was detected in cold processed tenera where it has a value of $28.537 \mathrm{mg} / 100 \mathrm{~g}$. This high value of the beta-carotenoid for the market samples can be attributed to the fact that the market samples are actually gotten from a mixture of several varieties including the wild grown varieties. Zeaxanthin has the second concentration after beta-carotenoid with the highest value of $9.400 \mathrm{mg} / 100 \mathrm{~g}$ observed in Eke Okigwe market sample, followed by $9.301 \mathrm{mg} / 100 \mathrm{~g}$ observed in Ahunta and Orie Ugba market. No regular pattern of either lowering or increasing in concentration of any of the carotenoids; these findings can be attributed to the fact that in the so-called hot processed, the samples are not heated to temperatures high enough to affect the carotenoid contents of the oil palm. As a result, the processing method does not affect the carotenoid profile of the oils. From Table 2 we can deduce that most dominant carotenoid present in the entire sample is $\beta$-carotenoid. This was in line with the result of [22] which says that $85 \%$ of the total crude palm oil is $\beta$-carotenoid. It can also be observed that the hot processed samples have higher values for all the carotenoids. While the market samples have the highest carotenoid values. This could be attributed to the fact that heat releases the carotenoids from the oil sample and makes it readily available for detection; this heat will eventually damage the carotenoid if the oil samples are further exposed to heat or sunlight [10]. Carotenoids have various functions in human health, such as antioxidant effects, eye health, heart health, improved cognitive function, and prevent certain types of cancer. $\beta$ carotene, the main dietary source of provitamin $\mathrm{A}$, is necessary for maintaining optimal human health [23] [24]. 
Table 2. Carotenoids profile of Oil samples.

\begin{tabular}{|c|c|c|c|c|c|c|c|c|c|c|c|}
\hline & \multirow{2}{*}{\multicolumn{2}{|c|}{ Dura $\mathrm{Mg} / 100 \mathrm{~g}$}} & \multirow{2}{*}{\multicolumn{2}{|c|}{ Pesifera Mg/100g }} & \multirow{2}{*}{\multicolumn{2}{|c|}{ Tenera Mg/100g }} & \multicolumn{3}{|c|}{$\mathrm{Mg} / 100 \mathrm{~g} \mathrm{Mg} / 100 \mathrm{~g} \mathrm{Mg} / 100 \mathrm{~g}$} & \multirow{3}{*}{$\begin{array}{c}\mathrm{Mg} / 100 \mathrm{~g} \\
\text { Ubani }\end{array}$} & \multirow{3}{*}{$\begin{array}{c}\mathrm{Mg} / 100 \mathrm{~g} \\
\text { Ukwunwa- } \\
\text { ngwu }\end{array}$} \\
\hline & & & & & & & & Eke- & & & \\
\hline & Hot & Cold & Hot & Cold & Hot & Cold & & Okigwe & Ugba & & \\
\hline$\beta$-cryptoxanthin & $\begin{array}{c}2.77 \pm \\
0.12\end{array}$ & $\begin{array}{c}1.97 b \pm \\
0.12\end{array}$ & $\begin{array}{c}3.22 \pm \\
0.12\end{array}$ & $\begin{array}{c}2.22 \pm \\
0.12 \mathrm{~b}\end{array}$ & $\begin{array}{c}3.96 \pm \\
0.12 \mathrm{a}\end{array}$ & $\begin{array}{c}3.03 \pm \\
0.12 \mathrm{~b}\end{array}$ & $\begin{array}{c}4.20 \pm \\
0.12 c\end{array}$ & $\begin{array}{c}4.20 \pm \\
0.12 c\end{array}$ & $\begin{array}{l}4.10 \pm \\
0.12 c\end{array}$ & $\begin{array}{c}4.20 \pm \\
0.12 \mathrm{c}\end{array}$ & $4.20 \pm 0.122 \mathrm{c}$ \\
\hline Lycopene & $\begin{array}{c}1.57 \pm \\
0.23 \mathrm{a}\end{array}$ & $\begin{array}{l}7.89 \pm \\
0.234 b\end{array}$ & $\begin{array}{c}1.85 \pm \\
0.23 \mathrm{~b}\end{array}$ & $\begin{array}{c}9.79 \pm \\
0.23 b\end{array}$ & $\begin{array}{c}2.22 \pm \\
0.23 \mathrm{~b}\end{array}$ & $\begin{array}{c}1.87 \pm \\
0.23 \mathrm{~b}\end{array}$ & $\begin{array}{c}2.30 \pm \\
0.11\end{array}$ & $\begin{array}{c}2.32 \pm \\
0.1 \mathrm{a}\end{array}$ & $\begin{array}{c}2.3 \pm \\
0.1 \mathrm{a}\end{array}$ & $\begin{array}{c}2.32 \pm \\
0.1 \mathrm{a}\end{array}$ & $2.32 \pm 0.1 \mathrm{a}$ \\
\hline$\alpha$-carotene & $\begin{array}{c}1.46 \mathrm{a} \pm \\
0.02\end{array}$ & $\begin{array}{c}1.16 \pm \\
0.02 \mathrm{a}\end{array}$ & $\begin{array}{c}1.99 \pm \\
0.02 \mathrm{a}\end{array}$ & $\begin{array}{c}1.26 \pm \\
0.02 \mathrm{a}\end{array}$ & $\begin{array}{c}1.944 \pm \\
0.02 \mathrm{a}\end{array}$ & $\begin{array}{c}1.69 \pm \\
0.02 \mathrm{a}\end{array}$ & $\begin{array}{c}2.00 \pm \\
0.03\end{array}$ & $\begin{array}{c}2.03 \pm \\
0.03 a\end{array}$ & $\begin{array}{l}2.0 \pm \\
0.03 b\end{array}$ & $\begin{array}{l}2.0 \pm \\
0.03 \mathrm{~b}\end{array}$ & $2.0 \pm 0.03 b$ \\
\hline$\beta$-carotene & $\begin{array}{c}63.62 \pm \\
0.31 \mathrm{a}\end{array}$ & $\begin{array}{c}55.89 \pm \\
0.31 \mathrm{a}\end{array}$ & $\begin{array}{c}76.81 \pm \\
0.31 \mathrm{a}\end{array}$ & $\begin{array}{c}59.81 \pm \\
0.31 \mathrm{a}\end{array}$ & $\begin{array}{c}81.89 \pm \\
0.31 \mathrm{a}\end{array}$ & $\begin{array}{c}28.54 \pm \\
0.31 \mathrm{a}\end{array}$ & $\begin{array}{c}84.18 \pm \\
0.10\end{array}$ & $84.2 \pm 0.1$ & $\begin{array}{c}83.99 \pm \\
0.1\end{array}$ & $\begin{array}{c}84.18 \pm \\
0.1\end{array}$ & $84.18 \pm 0.1$ \\
\hline Lutein & $\begin{array}{c}3.09 \pm \\
0.30 \mathrm{a}\end{array}$ & $\begin{array}{c}2.11 \pm \\
0.3 \mathrm{~b}\end{array}$ & $\begin{array}{l}3.66 \pm \\
0.3 .0 \mathrm{a}\end{array}$ & $\begin{array}{l}2.07 \pm \\
0.3 .0 \mathrm{~b}\end{array}$ & $\begin{array}{c}4.25 \pm \\
0.3 \mathrm{a}\end{array}$ & $\begin{array}{c}3.44 \pm \\
0.3 \mathrm{~b}\end{array}$ & $\begin{array}{c}4.82 \pm \\
0.15 c\end{array}$ & $\begin{array}{l}4.5 \pm \\
0.15 c\end{array}$ & $\begin{array}{c}4.82 \pm \\
0.15 c\end{array}$ & $\begin{array}{c}4.86 \pm \\
0.15 c\end{array}$ & $4.82 \pm 0.15 c$ \\
\hline Zea-xanthin & $\begin{array}{c}4.27 \pm \\
0.03 a\end{array}$ & $\begin{array}{c}5.60 \pm \\
0.03 b\end{array}$ & $\begin{array}{c}6.87 \pm \\
0.03 c\end{array}$ & $\begin{array}{c}5.83 \pm \\
0.03 b\end{array}$ & $\begin{array}{c}8.17 \pm \\
0.03 c\end{array}$ & $\begin{array}{l}4.98 \pm \\
0.027 \mathrm{a}\end{array}$ & $\begin{array}{c}9.30 \pm \\
0.2 \mathrm{c}\end{array}$ & $9.4 \pm 0.2 c$ & $\begin{array}{c}9.30 \pm \\
0.20 c\end{array}$ & $\begin{array}{c}9.30 \pm \\
0.2 \mathrm{c}\end{array}$ & $9.30 \pm 0.20 c$ \\
\hline Antheraxanthin & $\begin{array}{c}2.75 \pm \\
0.28 \mathrm{a}\end{array}$ & $\begin{array}{l}9.86 \pm \\
0.278 b\end{array}$ & $\begin{array}{c}3.769 \pm \\
0.28 \mathrm{a}\end{array}$ & $\begin{array}{c}1.42 \pm \\
0.28 \mathrm{c}\end{array}$ & $\begin{array}{c}4.11 \mathrm{~d} \pm \\
0.28\end{array}$ & $\begin{array}{l}3.20 \pm \\
0.278 \mathrm{a}\end{array}$ & $\begin{array}{c}4.61 \pm \\
0.3 \mathrm{~d}\end{array}$ & $\begin{array}{c}4.61 \pm \\
0.3 \mathrm{~d}\end{array}$ & $\begin{array}{l}4.61 \pm \\
0.31 \mathrm{~d}\end{array}$ & $\begin{array}{c}4.61 \pm \\
0.3 \mathrm{~d}\end{array}$ & $4.61 \pm 0.31 d$ \\
\hline Anstaxanthin & $\begin{array}{c}1.961 \pm \\
0.29 \mathrm{a}\end{array}$ & $\begin{array}{l}1.03 \pm \\
0.29 \mathrm{~b}\end{array}$ & $\begin{array}{c}2.16 \pm \\
0.29 \mathrm{a}\end{array}$ & $\begin{array}{l}1.67 \pm \\
0.29 b\end{array}$ & $\begin{array}{c}2.75 \pm \\
0.29 \mathrm{a}\end{array}$ & $\begin{array}{c}2.23 \pm \\
0.29 \mathrm{~b}\end{array}$ & $\begin{array}{c}3.05 \pm \\
0.4 \mathrm{c}\end{array}$ & $\begin{array}{c}3.05 \pm \\
0.4 \mathrm{c}\end{array}$ & $\begin{array}{c}3.06 \pm \\
0.41 \mathrm{c}\end{array}$ & $\begin{array}{c}3.05 \pm \\
0.4 c\end{array}$ & $3.05 c \pm 0.41 c$ \\
\hline Violaxanthin & $\begin{array}{c}4.07 \pm \\
0.31\end{array}$ & $\begin{array}{c}2.33 \pm \\
0.31\end{array}$ & $\begin{array}{c}2.33 \pm \\
0.31\end{array}$ & $\begin{array}{c}4.99 \pm \\
0.31\end{array}$ & $\begin{array}{c}2.36 \pm \\
0.31\end{array}$ & $\begin{array}{c}1.69 \pm \\
0.31\end{array}$ & $\begin{array}{c}2.35 \pm \\
0.31\end{array}$ & $2.35 \pm 0.1$ & $\begin{array}{c}2.35 \pm \\
0.06\end{array}$ & $2.5 \pm 0.1$ & $2.35 \pm 0.1$ \\
\hline Neoxanthin & $\begin{array}{c}4.07 \pm \\
3.0 \mathrm{a}\end{array}$ & $\begin{array}{c}2.33 \pm \\
3.00 \mathrm{~b}\end{array}$ & $\begin{array}{c}2.33 \pm \\
3.00 \mathrm{~b}\end{array}$ & $\begin{array}{c}4.99 \pm \\
3.00 \mathrm{a}\end{array}$ & $\begin{array}{c}5.78 \pm \\
3.0 \mathrm{~b}\end{array}$ & $\begin{array}{c}4.08 \pm \\
3.0 \mathrm{~b}\end{array}$ & $\begin{array}{c}6.37 \pm \\
1.04 \mathrm{c}\end{array}$ & $\begin{array}{c}6.37 \pm \\
1.0 \mathrm{c}\end{array}$ & $\begin{array}{c}6.37 \pm \\
1.04 \mathrm{c}\end{array}$ & $\begin{array}{c}6.37 \pm \\
1.0 \mathrm{c}\end{array}$ & $6.37 \pm 1.0 \mathrm{c}$ \\
\hline Total carotene & 89.62 & 90.17 & 104.99 & 94.028 & 117.43 & 54.735 & 123.18 & 123.03 & 122.89 & 123.39 & 123.199 \\
\hline
\end{tabular}

${ }^{*}$ Values are Means \pm standard deviations of triplicate determinations. Values in the same row having the same superscript letters are not significantly different $(\mathrm{p}<0.05)$.

\section{Conclusion}

Palm oil is a rich source of carotenoids. $\beta$-carotenoid makes up to about $85 \%$ of the carotenoid. It is the richest natural source of carotene in terms of provitamin activity. $\beta$-carotenoid protects against blindness and carcinogens. Processing method has little effect on the carotenoid properties and physicochemical characteristics therefore the choice of method should be based on the most efficient in terms of oil yield. The three different varieties vary slightly in both physicochemical properties and carotenoid characteristics, the commercially available oil samples (market samples) are the wildly grown varieties having just a little variation in physiochemical and carotenoid properties from the special varieties. Every part of the oil palm has economic and domestic values. The oils are useful for industrial, domestic and pharmaceutical formulations.

\section{Acknowledgements}

We thank the Chemistry laboratory of Abia State University Uturu, Nigeria for their support and providing necessary facilities in carrying out this research work. 


\section{Conflicts of Interest}

The authors declare no conflicts of interest regarding the publication of this paper.

\section{References}

[1] Rees, A.R. (2015) Evidence of the African Origin of Oil Palm Principles. Journal of Life Science, 2, 30-35.

[2] Bonnie, T.Y. and Choo, Y.M. (2016) Valuables Minor Constituents of Commercial Red Palm Olein; Carotenoid, Vitamin E, Ubiquinones and Sterols. Journal of Oil Palm Research, 12, 14-24.

[3] Goh, S.H., Choo, Y.M. and Ong, A.S.H. (1985) Minor Constituents of Palm Oil. Journal of the American Oil Chemists' Society, 62, 237-240. https://doi.org/10.1007/BF02541384

[4] Edem, D.O. (2002) Palm Oil: Biochemical, Physiological. Nutritional, Hematological, and Toxicological Aspect: A Review. Plant Foods for Human Nutrition, 137, 319-341. https://doi.org/10.1023/A:1021828132707

[5] Eric, B., Frederic, M., Lucien, H., Elmer, K. and Torsten, B. (2010) Comparison of 3 Spectorphotometric Methods for Carotenoid Determination in Frequently Consumer Fruit and Vegetables. Journal of Food Science, 75, 55-61. https://doi.org/10.1111/j.1750-3841.2009.01417.x

[6] Faessier, K. (2014) Palm Oil. American Journal of Oil Chemistry Society, 23, 6472-6477.

[7] Pearson, D.M. (1976) The Chemical Analysis of Foods. 6th Edition, AVI Publishers, West Port.

[8] AOCS (2005) Official Methods and Recommended Practices of the American Oil Chemists' Society.

[9] Yap, S.C., Choo, Y.M., Ooi, C.K., Ong, A.S.H. and Goh, S.H. (1991) Quantitative Analysis of Carotenes in the Oil from Different Palm Species. Journal of Oil Palm Research, 3, 369-378.

[10] Omokpariola, D.O., Okechukwu, V.U. and Omokpariola, P.L. (2021) Effects of Processing on the Nutritive and Anti-Nutritive Properties of Afzelia africana. Advanced Journal of Chemistry-Section B, 3, 188-198.

[11] Codex, A. (2011) Codex Standards for Named Vegetable Oils. Codex Publishers, Rome, Vol. 8, 12-22.

[12] Japir, A.A.W., Salimon, J., Derawi, D., Bahadi, M., Al-Shuja'a, S. and Yusop, M.R. (2017) Physicochemical Characteristics of High Free Fatty Acid Crude Palm Oil. OCL, 24, D506. https://doi.org/10.1051/ocl/2017033

[13] Okechukwu, V.U., Eze, S.O., Omokpariola, D.O. and Okereke, J.C. (2021) Evaluation of Phytochemical Constituents of Methanol Extract of Moringa oleifera Lam. Whole Leaf by Gas Chromatography-Mass Spectrometry and Fourier Transform Infrared Spectroscopy Analysis. World News of Natural Sciences, 37, 18-30.

[14] Omokpariola, D.O., Precious-Egere, S.C., Omokpariola, P.L. and Okechukwu, V.U. (2021) Phytochemical and Anti-Microbial Analysis of Metabolites in Seeds of Moringa oleifera Grown in Nigeria. Progress in Chemical and Biochemical Research, 4 , 268-277.

[15] Agatemor, C. (2006) Studies of Selected Physicochemical Properties of Fluted Pumpkin (Telfairia occidentalis Hook F.) Seed Oil and Tropical Almond (Termina- 
lia catappia L.) Seed Oil. Pakistan Journal of Nutrition, 5, 306-307. https://doi.org/10.3923/pjn.2006.306.307

[16] Suja, K.P., Abraham, J.T., Thamizah, S.N., Jayalekshmy, A. and Arumughan, C. (2004) Antioxidant Efficacy of Sesame Cake Extract in Vegetable Oil Production. Food Chemistry, 84, 393-400. https://doi.org/10.1016/S0308-8146(03)00248-6

[17] Onwuka, G.I. (2015) Peroxide Value. In: Food Analysis and Instrumentation: Theory and Practical, Naphthali Prints, Lagos, 70-72.

[18] Aremu, M.O. and Amos, V.A. (2010) Fatty Acids and Physicochemical Properties of Sponge Luffa (Luffa cylindrical) Kernel Oil. International Journal of Chemical Sciences, 3, 161-166.

[19] Abdulkadir, A.G. and Jimoh, W.L.O. (2013) Comparative Analysis of PhysicoChemical Properties of Extracted and Collected Palm Oil and Tallow. ChemSearch Journal, 4, 44-54.

[20] Nigerian Institute for Oil and Palm Research (1978-1979) Fifteenth Annual Report. Characteristics of Palm Oil. NIFOR.

[21] Saini, R.K. and Keum, S.Y. (2018) Significance of Genetic, Environmental, and Preand Postharvest Factors Affecting Carotenoid Contents in Crops: A Review. Journal of Agricultural and Food Chemistry, 66, 5310-5324. https://doi.org/10.1021/acs.jafc.8b01613

[22] Sundram, K., Sambanthamurthi, R. and Tan, Y.A. (2003) Palm Fruit Chemistry and Nutrition. Asia Pacific Journal of Clinical Nutrition, 12, 355-362.

[23] Roomi, M.W., Niedzwiecki, A. and Rath, M. (2018) Scientific Evaluation of Dietary Factors in Cancer. Journal of Nutritional Medicine and Diet Care, 4, 1-13. https://doi.org/10.23937/2572-3278.1510029

[24] Zhou, X., Wang, H., Wang, C., Zhao, C., Peng, Q., Zhang, T. and Zhao, C. (2018) Stability and in Vitro Digestibility of Beta-Carotene in Nanoemulsions Fabricated with Different Carrier Oils. Food Science and Nutrition, 6, 2537-2544. https://doi.org/10.1002/fsn3.862 